\title{
The Influence of Authoritarian Parenting on the Development of Early Childhood Creativity
}

\author{
Laila Fitriana ${ }^{1}$, Lusila Andriani Purwastuti ${ }^{2}$ \\ ${ }^{1}$ Graduate School of Early Childhood Education, Yogyakarta State University, Indonesia \\ ${ }^{2}$ Graduate School of Philosophy and Sociology of Education, Yogyakarta State University, Indonesia \\ *Corresponding e-mail: lailafitriana.2018@student.uny.ac.id
}

Received: 04 July 2020

Accepted: 09 August 2020

Published: 20 August 2020

Abstract: The Influence of Authoritarian Parenting on the Development of Early Childhood Creativity. Objectives: This study aims to reveal whether there is an influence of authoritarian parenting on the development of early childhood creativity. Methods: Ex Post Facto quantitative research involved 100 children aged 4-5 years and their parents, and 18 teachers from 9 kindergartens in Jambi City. Data were analyzed using simple linear regression analysis to reveal the effect of authoritarian parenting on the development of creativity. Findings: Simple linear regression test for authoritarian parenting has a significance value of $0.003(\mathrm{P}<0.05)$ which means that it influences children's creativity, children become unconfident, afraid to do something, and children tend to be quieted. Parents who apply the majority authoritarian parenting background in high school education. Conclusion: There is a negative influence of authoritarian parenting on the development of early childhood creativity.

Keywords: authoritarian parenting, development of creativity, early childhood.

Abstrak: Pengaruh Pola Asuh Otoriter terhadap Perkembangan Kreativitas Anak Usia Dini. Tujuan: Penelitian ini bertujuan untuk mengungkapkan apakah terdapat pengaruh pola asuh otoriter terhadap perkembangan kreativitas anak usia dini. Metode: Penelitian kuantitatif Ex Post Facto melibatkan 100 anak usia 4-5 tahun beserta orang tuanya, dan 18 guru dari 9 Taman Kanak-kanak di Kota Jambi. Data dianalisis menggunakan analisis regresi linier sederhana untuk mengungkapkan pengaruh pola asuh otoriter terhadap perkembangan kreativitas. Temuan: Uji regresi linier sederhana untuk pola asuh otoriter memiliki nilai signifikansi 0,003 $(P<0,05)$ yang berarti mempengaruhi kreativitas anak, anak menjadi tidak percaya diri, takut untuk melakukan sesuatu, dan anak cenderung pendiam. Orang tua yang menerapkan pola asuh otoriter mayoritas berlatar belakang pendidikan sekolah menengah. Kesimpulan: Terdapat pengaruh negatif pola asuh otoriter terhadap perkembangan kreativitas anak usia dini.

Kata kunci: pola asuh otoriter, perkembangan kreativitas, anak usia dini.

\section{To cite this article:}

Fitriana, L., \& Purwastuti, L., A. (2020). The Influence of Authoritarian Parenting on The Development of Early Childhood Creativity. Jurnal Pendidikan Progresif, 10(2), 267-278. doi: 10.23960.jpp.v10.i2.202011 


\section{INTRODUCTION}

Early childhood is a child whose age has not yet entered a formal education institution such as elementary school (ES) and usually they remain at home or participate in activities in preschool educational institutions (Hasnida, 2014). Childhood is a unique time, a learning period that is very important for the development of an individual (Lesmana, 2011). Early childhood is also said to be a creative period. At this time, children really need help from others.

The main education obtained by children comes from the family, the child first gets a stimulus in the family environment and the most time is spent by the child also in the family. The family environment provides learning patterns and facilities in the form of parenting style (Theresya, Melly, \& Neti, 2018). The style of nurture studied extensively for human development begins in childhood (Kordi, 2010).

Parenting style is a strong predictor for hereditary outcomes (Levinson, et al., 2016; Niaraki \& Hassan, 2012). Parenting style is very important in the learning and development process of children, because parenting style represents the emotional connection and quality of interaction between parents and their children (Moradian, Alipour, \& Shahani-Yailagh, 2014).

Parents have a very influential role in providing stimulation as an effort to develop children's creativity. This role can be realized through the application of appropriate parenting. Authoritarian parenting is very strict, expecting, controlling, and rigid parenting style with the aim of keeping their children safe and secure, but they often forget the consequences on children's health (Jadon \& Tripathi, 2017).

Authoritarian parenting is also called dictatorial or hard, low warmth, strict and disciplined care, high parent to child communication, low child to parent communication, and high parent expectations (Niaraki \& Hassan, 2012). Authoritarian parenting is a parenting style that prefers to shape the child's personality by setting absolute standards that must be followed, one-way communication, limiting children, not giving guidance to children, and usually followed by threats (Stewart and Koch, 1983). Authoritarian parenting is the most disciplined style of parenting. Authoritarian parents have high demands and low responsiveness (Levinson, et al., 2016).

Parents who apply authoritarian parenting have characteristics including: rigid, assertive, punitive, lacking affection and sympathy, forcing children to obey their values, trying to shape the behavior of children, and tend to curb the wishes of children (Stewart \& Koch, 1983). In parenting like this, the demands of children are too high whereas parents are not responsive at all. This type of parenting is very tight and rigid. Parents impose strict and rigid rules on children that must be followed, any non-compliance with the rules or orders of the parents directly means punishment, authoritarian parents use physical punishment such as hitting, usually the explanation of punishment is "just because they say so". (Jadon \& Tripathi, 2017).

The authoritarian style has a low level of acceptance and close ties, a high level of mandatory control and a low level of independence (Moradian, Alipour, \& ShahaniYailagh, 2014). Authoritarian parents firmly control the practice of their children, expect strict compliance, parental authority is not questioned, are not ready to accept the child's individuality, face disobedience with strong discipline and punishment, relatively neglect the child's needs, and have very behavior direct and little communication with children (Mehrinejad, Sara, \& Mahdieh, 2015).

The way parents take care of their children has an impact on the development of the child's personality, social interactions (including children's creativity), and from close 
relationships with significant others (Mahasneh, Zohair, Omar, \& Mohammad, 2013). Many problems of internationalization and externalization in boys and girls are related to authoritarian parenting (Akhtar, Malik, \& Begeer, 2016; Braza et al., 2013; Calzada, Barajas-Gonzalez, Huang \& Brotman, 2017; Cheung, 2014 Clark, Dahlen, \& Nicholson, 2015; Hartman et al., 2015; King, Vidourek, \& Merianos, 2016; Moed, Gershoff, \& Bringewatt, 2016; Pellerone, Tolini, \& Polopoly, 2016; Tavassolie, et al., 2016; Wood \& Kennison, 2017; Yaffe, 2017).

When the independent evolution of an authoritarian style is limited, parents use punishment to control their child's behavior (Moradian, Alipour, \& Shahani-Yailagh, 2014). As a result, children of such parents often foster negative thoughts and are afraid of experiencing new things. Therefore, excessive inhibition by parents with an authoritarian parenting style will be an obstacle to their children's creativity (Tanhaye-Reshvanlou \& Hejazi, 2009).

The seeds of creativity are formed early in life and are nurtured for many years in families and schools (Pham \& Betsy, 2019). Creativity is the ability to think in new and unique ways (Hasanzadeh \& Imanifar, 2011). Creativity is increasingly recognized as a characteristic of someone who can and must be developed through the world of education, both formal and informal.

Various characteristics of creativity according to Rachmawati \& Kurniati (2012) are that children have a great curiosity about a thing / are open to new experiences, have self-confidence and are independent, have a sense of beauty / aesthetic high, and are able to produce a work / are interested on creative activities. Creativity involves someone to produce creative products. Originality is usually identified as one of the main characteristics in the ability to bring forth ideas / ideas and also the involvement of imaginative activities. (Sharp, 2001). When a student is criticized by parents and teachers for experiencing new things, his creativity is prevented because of this obstacle in conflict with personality traits of creative individuals (Alborzi, 2012).

The role of parents is needed in developing creativity, but must still be adjusted to the needs of children (Akdaç \& Haser, 2010). Many parents are less aware of how to properly educate children, resulting in disruption to the child's own development such as children feel their freedom is restricted, children feel unappreciated because their opinions have never been heard, children feel too governed by their parents so that children feel helpless, and children feel afraid to do something because it was never considered right by their parents, children are not given the opportunity to express their ideas and desires.

The creativity generated by children from parental authoritarian parenting tends to be lower, because children are not given the freedom to create so that children feel inferior to do new things for fear of making mistakes (Rachmawati, \& Kurniati, 2012). Applying parenting that is appropriate for the child can optimize the development of children's creativity. However, what often happens is that parents put forward the brain or cognitive development of children and assume the smart child is a child who is fast in learning to count, read, and write, without regard to the process and prioritizes the results.

The results show that authoritarian parenting style has a significant negative relationship with creativity, and is the most prominent predictor of creativity in children (Fearon, Daelynn, \& Terrill, 2013; Mehrinejad, Sara, \& Mahdieh, 2015). ANOVA shows that having authoritarian parents is associated with the most unfavorable results compared to other parents (Kuppens \& Eva, 2018). In addition, the TEPS analysis shows that authoritarian parenting is negatively related to children's school performance (Pong, Johnston, \& Chen, 2009). 
In this study, the author wants to express the influence of authoritarian parenting on the development of early childhood creativity. This is done in order to obtain evidence and data related to the influence of authoritarian parenting on the development of children's creativity. It is expected to provide information to the community, parents, prospective parents, and teachers to be able to apply maximum parenting that can improve all aspects of child development, especially the development of creativity which is often overlooked. This study needs to consider the importance of parenting in the family to help improve children's development and can produce a creative generation in Indonesia.

\section{METHOD}

This study used a quantitative method (ex post facto) which aims to reveal the influence of authoritarian parenting on the development of children's creativity. This type of ex post facto research was conducted empirically and systematically so that it could reveal the cause of an event that occurred without manipulating the phenomenon (Siregar, 2014). This research involves two types of variables, namely dependent and independent. The independent variable in this study is Authoritarian Parenting (X1), while the dependent variable (the influenced variable) is the Development of Children's Creativity (Y). This research was conducted in 9 kindergartens in Jambi City, Indonesia for 2 months (October to December 2019).

The population in this study is children aged 4-5 years who are attending kindergarten in Jambi City who have authoritarian parents. Samples were taken using the total sampling method, so that the entire population was sampled and 100 children were obtained consisting of 43 boys and 57 girls.

This study uses the technique of applying instruments in the form of questionnaires to measure authoritarian parenting and the development of children's creativity. The questionnaire instrument used in this study was created based on the theoretical concepts of Stewart \& Koch (1983) for the authoritarian parenting questionnaire and the theoretical concept of Treffinger \& Taylor (Masnipal, 2013) for the creativity development questionnaire. The questionnaire uses a likert scale (5 scale). Parenting questionnaire is given to parents through school and brought home to be filled in by parents to later be returned to the school, creativity questionnaire is given to the teacher to be filled out by the teacher to find out the child's creativity development and returned after completion.

Before instruments are used to measure variables, existing instruments must be validated to experts (lecturers) for content-related validation. The results of the instrument validation were then tested on 32 parents (father or mother) and kindergarten teachers in Jambi City who had ages between $22-45$ years. The construct validity was performed using SPSS using Pearson Correlation. Items are declared valid if the r count is greater than $r$ table and the significance value is less than $0.05(\mathrm{P}<0.05)$. The following are the results of validity in this study.

Table 1. Validity of authoritarian parenting

\begin{tabular}{cccc}
\hline & r count & Sig. & \\
\hline Item1 & 0.385 & 0.029 & Valid \\
Item2 & 0.355 & 0.046 & Valid \\
Item3 & 0.352 & 0.048 & Valid \\
Item4 & 0.358 & 0.044 & Valid \\
Item5 & 0.361 & 0.042 & Valid \\
Item6 & 0.385 & 0.030 & Valid \\
Item7 & 0.370 & 0.037 & Valid \\
Item8 & 0.358 & 0.044 & Valid \\
Item9 & 0.373 & 0.036 & Valid \\
Item10 & 0.373 & 0.036 & Valid \\
Item11 & 0.380 & 0.032 & Valid \\
Item12 & 0.493 & 0.004 & Valid \\
Item13 & 0.370 & 0.037 & Valid \\
Item14 & 0.359 & 0.044 & Valid \\
Item15 & 0.368 & 0.038 & Valid \\
Item16 & 0.392 & 0.026 & Valid
\end{tabular}




\begin{tabular}{llll} 
Item17 & 0.358 & 0.045 & Valid \\
Item18 & 0.388 & 0.028 & Valid \\
Item19 & 0.411 & 0.019 & Valid \\
Item20 & 0.381 & 0.031 & Valid \\
Item21 & 0.439 & 0.012 & Valid \\
Item22 & 0.367 & 0.039 & Valid \\
Item23 & 0.372 & 0.036 & Valid \\
Item24 & 0.359 & 0.044 & Valid \\
Item25 & 0.367 & 0.039 & Valid \\
Item26 & 0.480 & 0.005 & Valid \\
Item27 & 0.422 & 0.016 & Valid \\
Item28 & 0.439 & 0.012 & Valid \\
Item29 & 0.472 & 0.006 & Valid \\
Item30 & 0.448 & 0.010 & Valid \\
\hline
\end{tabular}

Based on the results of the calculation of validity it is known that the $r$ count for all items is greater than 0.3494 and the significance value is smaller than 0.05 , so it can be stated that the parent's instrument knowledge of the variable is declared valid.

Table 2. Validity of children's creativity development

\begin{tabular}{cccc}
\hline & r count & Sig. & \\
\hline Item1 & 0.372 & 0.036 & Valid \\
Item2 & 0.387 & 0.029 & Valid \\
Item3 & 0.419 & 0.017 & Valid \\
Item4 & 0.359 & 0.044 & Valid \\
Item5 & 0.361 & 0.042 & Valid \\
Item6 & 0.399 & 0.024 & Valid \\
Item7 & 0.506 & 0.003 & Valid \\
Item8 & 0.399 & 0.024 & Valid \\
Item9 & 0.414 & 0.019 & Valid \\
Item10 & 0.399 & 0.024 & Valid \\
Item11 & 0.373 & 0.035 & Valid \\
Item12 & 0.394 & 0.026 & Valid \\
Item13 & 0.407 & 0.021 & Valid \\
Item14 & 0.370 & 0.037 & Valid \\
Item15 & 0.542 & 0.001 & Valid \\
Item16 & 0.518 & 0.002 & Valid \\
Item17 & 0.536 & 0.002 & Valid \\
Item18 & 0.420 & 0.017 & Valid \\
Item19 & 0.362 & 0.042 & Valid \\
Item20 & 0.377 & 0.033 & Valid \\
Item21 & 0.423 & 0.016 & Valid \\
Item22 & 0.417 & 0.017 & Valid \\
Item23 & 0.411 & 0.020 & Valid \\
Item24 & 0.439 & 0.012 & Valid
\end{tabular}

\begin{tabular}{llll} 
Item25 & 0.455 & 0.009 & Valid \\
Item26 & 0.428 & 0.014 & Valid \\
Item27 & 0.390 & 0.027 & Valid \\
Item28 & 0.490 & 0.004 & Valid \\
Item29 & 0.529 & 0.002 & Valid \\
Item30 & 0.366 & 0.039 & Valid \\
\hline
\end{tabular}

Based on the results of the calculation of validity it is known that the r count for all items is greater than 0.3494 and the significance value is less than 0.05 , so it can be stated that the teacher's knowledge of the variable is declared valid.

After testing the instrument validity, the instrument reliability test is then performed. Reliability tests were carried out with SPSS using Cronbach Alpha. The questionnaire was declared reliable if the Cronbach alpha value was more than 0.6 (Sujarweni, 2014). The following are the results of the reliability in this study.

Table 3. Reliability statistics of authoritarian parenting

\begin{tabular}{|c|c|}
\hline \multicolumn{2}{|c|}{ Reliability Statistics } \\
\hline $\begin{array}{c}\text { Cronbach's } \\
\text { Alpha }\end{array}$ & $\mathrm{N}$ of Items \\
\hline .802 & 30 \\
\hline $\begin{array}{l}\text { Based on the } \\
\text { lity, it is know } \\
\text { is greater th } \\
\text { e stated that } \\
\text { le variables }\end{array}$ & $\begin{array}{l}\text { of the calc } \\
\text { ne value of } \\
\text { which is } 0 \\
\text { athoritarian } \\
\text { ble. }\end{array}$ \\
\hline
\end{tabular}

Table 4. Reliability statistics of the development of children's creativity

\begin{tabular}{cc}
\multicolumn{2}{c}{ Reliability Statistics } \\
\hline $\begin{array}{c}\text { Cronbach's } \\
\text { Alpha }\end{array}$ & N of Items \\
\hline .836 & 30 \\
\hline
\end{tabular}

Based on the results of the calculation of reliability, it is known that the value of Cronbach's Alpha is greater than 0.6 , which is 0.836 so that it can be stated that the variable 
of children's creativity development variables can be relied upon.

Parenting questionnaire sheet filled out by parents (father or mother) in accordance with the reality of what happened. Parents provide a check list on each item. Parents are asked to rate on a 5 point scale how well each item describes itself. The complete size consists of 30 items that describe authoritarian parenting. Four factors were identified: (1) One-Way Communication (e.g. "Refusing to hear a child's opinion"); (2) Restricting Children (e.g. "Prohibiting children from being friends"); (3) Without Guidance (eg "Avoid discussing with children"); and (4) Punishment (e.g. "Providing punishment that embarrasses children").

Creativity questionnaire sheets are used by teachers during the learning process through activities that have been prepared by the teacher without disrupting the child's learning process. The teacher only gives a sign for each occurrence of the intended symptom. The teacher is asked to rate on a 5 point scale, how well each item describes the child. The complete size consists of 30 items that describe the development of children's creativity. Four factors were identified: (1) Great Curiosity (e.g "Many questions"); (2) Confidence (e.g "Always optimistic"); (3) Have a Sense of Beauty (e.g "Often give praise"); and (4) Producing Work (e.g "Drawing").

After the data is obtained, then data processing is taken based on samples and the results of data processing are obtained through statistical analysis. The first analysis is the normality test (Kolmogorov-Smirnov test) to find out whether the data to be analyzed is in the form of normal distribution or not, in other words the sample from the population in the form of data is normally distributed or not. Then the linearity test (ANOVA) to find out whether the equation model obtained is suitable / not. After conducting normality and linearity tests, the data are then analyzed using linear regression analysis to reveal the influence of authoritarian parenting on the development of children's creativity. The results of the analysis are used to interpret how the influence of authoritarian parenting on the development of early childhood creativity.

\section{RESULT AND DISCUSSION}

The results of this study consist of three parts, namely the results of the normality test (Kolmogorov Smirnov test), linearity test (ANOVA), and simple linear regression analysis. Normality test is conducted to determine whether the distribution obtained is normally distributed or not, and then used to determine the research hypothesis testing technique. Normality test for both variables was carried out using the Kolmogorov Smirnov test with a significance level of $0.05(\mathrm{P}>0.05)$. The normality test results can be seen in table 1 .

Table 1. Score of normality test

\begin{tabular}{lcr}
\hline & & $\begin{array}{c}\text { Unstandardized } \\
\text { Residual }\end{array}$ \\
\hline $\mathrm{N}$ & Mean & 100 \\
Normal & $0 \mathrm{E}-7$ \\
Parameters $^{\mathrm{a}, \mathrm{b}}$ & Std. & 5,13104162 \\
& Deviation &, 054 \\
Most & Absolute &, 054 \\
Extreme & Positive &,- 049 \\
Differences & Negative &, 542 \\
Kolmogorov & &, 930 \\
-Smirnov Z & & \\
Asymp. Sig. & & \\
(2-tailed) & & \\
\hline
\end{tabular}

Based on the table of normality test results in table 1 which shows that the significance value of the two variables is 0.930 . If the significance is less than 0.05 , then the conclusion is that the data is not normally distributed, if the significance is more than 0.05 , then the data is normally distributed(Purnomo, 2016). This shows that the 
significance value is greater than the alpha value of $0.05(\mathrm{P}>0.05)$, so Ha is rejected and Ho is accepted. It can be concluded that the authoritarian parenting data and the development of early childhood creativity obtained from parents and teachers come from populations with a normal distribution, so the data can be used for further analysis.

Further analysis of the linearity test is performed to determine whether the data on the dependent variable and the independent variable have a linear relationship or not. Testing on SPSS uses Test for Linearity at a significance level of 0.05 . Two variables are said to have a linear relationship if the significance (Linearity) is less than 0.05 and the Deviation from Linearity is more than 0.05 (Purnomo, 2016). If the probability is more than 0.05 then the model is rejected and if the probability is less than 0.05 then the model is accepted. The linearity test results can be seen in table 2 . value in the Deviation for Linearity, the significance value of 0.499 is more than 0.05 , it can be concluded that there is a linear relationship between authoritarian parenting variables and the development of early childhood creativity and linearity tests have been fulfilled.

This linear relationship occurs because parenting is a strong predictor for hereditary outcomes (Levinson, et al., 2016; Niaraki \& Hassan, 2012). In addition, parenting is also very important in the learning process and development of children (Moradian, Alipour, \& Shahani-Yailagh, 2014). Akdaç \& Haser (2010) argues that the role of parents is needed in developing creativity, but must still be adapted to the needs of children. After knowing the results of the linearity test, the next analysis will test the hypothesis.

Based on the results of normality and linearity tests that have been stated to meet the

Table 2. Score of linearity test

ANOVA Table

\begin{tabular}{|c|c|c|c|c|c|c|c|}
\hline & & & $\begin{array}{l}\text { Sum of } \\
\text { Squares }\end{array}$ & $\mathrm{df}$ & $\begin{array}{l}\text { Mean } \\
\text { Square }\end{array}$ & $\mathrm{F}$ & Sig. \\
\hline \multirow{5}{*}{$\begin{array}{l}\text { creativity* } \\
\text { authoritarian }\end{array}$} & \multirow{3}{*}{ Between Groups } & (Combined) & 625,366 & 16 & 39,085 & 1,462 &, 134 \\
\hline & & Linearity & 238,319 & 1 & 238,319 & 8,913 &, 004 \\
\hline & & $\begin{array}{l}\text { Deviation from } \\
\text { Linearity }\end{array}$ & 387,047 & 15 & 25,803 & ,965 & ,499 \\
\hline & Within Groups & & 2219,384 & 83 & 26,740 & & \\
\hline & Total & & 2844,750 & 99 & & & \\
\hline
\end{tabular}

Based on the linearity test table in table 2 (ANOVA table), this shows that the linearity test results of the authoritarian parenting variables and the development of early childhood creativity have a value of $F$ count $=8.913$ with a significance of 0.004 less than 0.05 . This shows that authoritarian parenting has a linear relationship with the development of early childhood creativity. If seen from the significance requirements, the research analysis can proceed with hypothesis testing using simple linear regression analysis. Simple linear regression testing using a significance level of 0.05 means the chance of obtaining a maximum error of $5 \%$, in other words that $95 \%$ of the decisions are correct (Purnomo, 2016). Data from the results of simple linear regression analysis are presented in Table 3. 
Tabel 3. Linear regression test

Coefficients $^{\mathrm{a}}$

\begin{tabular}{|c|c|c|c|c|c|c|}
\hline & \multirow[t]{2}{*}{ Model } & \multicolumn{2}{|c|}{ Unstandardized Coefficients } & \multirow{2}{*}{$\begin{array}{c}\begin{array}{c}\text { Standardized } \\
\text { Coefficients }\end{array} \\
\text { Beta } \\
\end{array}$} & \multirow[t]{2}{*}{$\mathrm{t}$} & \multirow[t]{2}{*}{ Sig. } \\
\hline & & $\mathrm{B}$ & Std. Error & & & \\
\hline \multirow{2}{*}{1} & (Constant) & 31,718 & 14,752 & & 2,150 &, 03 \\
\hline & authoritarian &, 415 &, 138 & ,289 & 2,993 &, 003 \\
\hline
\end{tabular}

a. Dependent Variable: developmentofcreativity

Based on the table of the results of simple linear regression analysis in table 3 (coefficient table), this shows that the significance value of authoritarian parenting is 0.003 less than 0.05 , which means that authoritarian parenting has an influence on the development of early childhood creativity due to the observation hypothesis (Ho) is rejected and the alternative hypothesis $(\mathrm{Ha})$ is not rejected (accepted). It can be concluded that authoritarian parenting has a significant influence on the development of early childhood creativity. Following are the results of the regression equation obtained.

$$
Y=31,718+\mathbf{0 . 4 1 5 X}
$$

The constant value (a) is 31,718 which means that if the authoritarian parenting value is 0 , then the development of early childhood creativity is worth 31,718 . The beta coefficient (b) has a positive value of 0.415 which means that any additional value of 1 in authoritarian parenting will increase the value of conformity of 0.415 in the development of early childhood creativity.

In the coefficient table there is one independent variable $(\mathrm{X})$ included in the regression model. The authoritarian parenting variable has a $\mathrm{t}$-value of statistics ( $\mathrm{t}$ count) 2,993 and t table 100 is 1,66055 $(\mathrm{N}=100-2$ (degrees of freedom) $=$ 98), so $t$ count $>t$ table $(2,993>1,66055)$ and significance $<0.05(0.003<0.05)$, then Ho is rejected, which means that authoritarian parenting has a significant influence on the development of early childhood creativity.
The results of this conclusion are in line with the theory of Mahasneh, Zohair, Omar, \& Mohammad (2013) that the way parents take care of their children has an impact on the development of the child's personality, social interactions (including children's creativity), and from significant close relationships with others. The application of authoritarian parenting makes children depressed and inhibits the development of children's creativity, in line with the theory of Rachmawati \& Kurniati (2012) which states that the creativity produced by children from authoritarian parenting tends to be lower, because children are not given the freedom of creation so that children feel inferior to do new things for fear of making mistakes.

This is in line with research conducted by Fearon, Daelynn, \& Terrill (2013); Mehrinejad, Sara, \& Mahdieh (2015), in which the results of the study show that authoritarian parenting style has a significant negative relationship with creativity, and is the most prominent predictor of creativity in children. Likewise, research conducted by Kuppens \& Eva (2018) where ANOVA shows that having authoritarian parents is associated with the most unfavorable results compared to other parents, including in the creativity of children.

Parenting parents toward their children in the early days is an event that is expected by children. This is very important in the context of efforts to develop children's creativity in the future. 
Each family has different parenting style in caring for and guiding children. In families we often meet parents who apply harshly to their children. All rules that have been determined by parents must be obeyed if the child violates the rules, the parents will be angry, as a result the child will be threatened and punished this causes the child will experience a decline in creativity.

In this study, authoritarian parenting applied by parents is more inclined to actions that forbid, govern or control the child of their own volition, more threats and punishment, and children are not given the opportunity to express their wishes. Thus, children become insecure, are always afraid of making mistakes, and children become very quiet, as a result the development of children's creativity is lower than other children.

Educational background of respondents ranging from high school to undergraduate, as well as the work of respondents ranging from housewives, laborers, to employees also greatly affect the authoritarian parenting that is applied in parenting. The level of education has an influence in choosing the right parenting, and socioeconomic status also influences the choice of parenting. This is in line with the opinion of Jadon \& Tripathi (2017) that there are various factors that influence the type of care a person uses to raise their children, these factors can be cultural differences, family social and economic conditions, family socioeconomic status, values and their beliefs, and family social classes also play an important role in the child care process. In this study the majority of respondents had a high school education background and the majority of the work were housewives (mothers) or laborers (fathers).

Parenting is an important factor in developing or inhibiting the emergence of creativity (Rachamawi \& Kurniati, 2012). Strict and strict parenting, where parents always forbid and punish children when they make mistakes in playing or doing something related to creativity, as a result children become insecure and easily give up in doing an activity, and feel insecure to friends their friend.

Parenting patterns can influence children to do something. The right parenting that gives children the opportunity to express their opinions, discuss more with the child, and advise the child in a good way can help develop children's creativity. Hopefully, parents can choose the right parenting style by paying attention to the child's condition, as well as knowing the positives and negatives of the parenting style adopted, and the teacher can carry out routine parenting activities at school to explain the application of appropriate parenting for early childhood so as to develop creativity child.

\section{- CONCLUSION}

Based on the results of the linear regression test on the influence of authoritarian parenting on the development of early childhood creativity in kindergarten Jambi City, it can be concluded that there is a negative influence of the authoritarian parenting on the development of early childhood creativity in kindergarten Jambi City. Based on the information presented in this study, it is suggestion for teachers to be able to improve their skills and knowledge in communicating with parents about the development of children's creativity. This is because the teacher's understanding of parenting can help in providing services and guidance to children so that children's creativity can develop properly.

\footnotetext{
REFERENCES

Akdaç, Z., \& Haser, Ç. (2010). Beginning early childhood education teacher's problems in Turkey. Procedia - Social and Behavioral Sciences, 9, 884-889.

Akhtar, P., Malik, J. A., \& Begeer, S. (2016). The grandparents' influence: parenting styles and social competence among children of joint families. Journal of Child and Family Studies, 26, 603-611.
} 
Alborzi, M.(2012). The role of parenting beliefs and attitude to children's creative thinking creativity. Psychological and Social Studies of Women, 9, 7-24.

Braza, P., Carreras, R., Muñoz, J. M., Braza, F., Azurmendi, A., Pascual-Sagastizábal, E., \& Sánchez-Martín, J. R. (2013). Negative maternal and paternal parenting styles as predictors of children's behavioral problems: Moderating effects of the child's sex. Journal of Child and Family Studies, 24, 847-856.

Calzada, E., Barajas-Gonzalez, R., Huang, K., \& Brotman, L. (2017). Early childhood internalizing problems in Mexican- and dominican-origin children: The role of cultural socialization and parenting practices. Journal of Clinical Child and Adolescent Psychology, 46, 551-562.

Cheung, K. (2014). Relations between parenting behaviors, parent traits, and children's social competence in Chinese immigrant families (Order No. AAI3567246). Available from PsycINFO. (1520900103; 2014-99080308). https://search.proquest.com/ docview/1520900103?accountid=14512.

Clark, C. M., Dahlen, E. R., \& Nicholson, B. C. (2015). The role of parenting in relational aggression and prosocial behavior among emerging adults. Journal of Aggression, Maltreatment \& Trauma, 24, 185-202.

Fearon, Danielle D., Daelynn Copeland., \& Terrill F. Saxon. (2013). The relationship between parenting styles and creativity in a sample of Jamaican children. Creativity Research Journal, 25(1), 119-128.

Hartman, J. D., Patock-Peckham, J. A., Corbin, W. R., Gates, J. R., Leeman, R. F., Luk, J. W., \& King, K. M. (2015). Direct and indirect links between parenting ptyles, self-concealment (secrets), impaired control over drinking and alcohol-related outcomes. Addictive Behaviors, 40, 102-108.

Hasanzadeh, R., \& Imanifar, P. (2011). The relationship between creativity and selfesteem and academic achievement of adolescent and youth. Journal of Professional Sociology, 1, 55-56.

Hasnida. (2014). Analisis kebutuhan anak usia dini [Analysis of early childhood needs]. Jakarta Timur: PT Luxima Metro Media. Jadon, Priyansha Singh., \& Tripathi Shraddha. (2017). Effect of authoritarian parenting style on self esteem of the child: A systematic review. IJARIIE, 3(3), 909913. ISSN(O)-2395-4396.

King, K.A., Vidourek, R. A., \& Merianos, A. L. (2016). Authoritarian parenting and youth depression: Results from a national study. Journal of Prevention \& Intervention in the Community, 44, 130-39.

Kordi, Abdorreza. (2010). Parenting attitude and style and its effect on children's school achievments. International Journal of Psychological Studies, 2(2), 217-219.

Kuppens, Sofie., \& Eva, C. (2018). Parenting style: A closer look at a well-known concept. Journal of Child and Family Studies (2019) 28, 168-181.

Lesmana, Jeanette Murad. (2011). Dasardasar konseling [Basics of counseling]. Jakarta: Penerbit Universitas Indonesia (UI-Press).

Levinson, A.R., Brittany, C.S., Brady, N., Jennifer, N.B., \& Greg, H. (2016). Authoritarian parenting predicts reduced electrocortical response to observed. Oxford University Press. http:/ /scan.oxfordjournals.org/ at Cornell University Library.

Mahasneh, Ahmad M., Zohair, H. Al-Zoubi., Omar, T. Batayenh., \& Mohammad, S. Jawarneh. (2013). The relationship 
between parenting styles and adult attachment styles from Jordan University students. International Journal of Asian Social Science, 3(6), 1431-1441.

Masnipal. (2013). Siap menjadi guru dan pengelola PAUD profesional [Ready to become a teacher and professional ECE manager]. Jakarta: PT Gramedia.

Mehrinejad, S.A., Sara, R., \& Mahdieh, T. (2015). The relationship between parenting style and creativity and the predictability of creativity by parenting styles. Procedia - Social and Behavioral Sciences, 56-60.

Moed, A., Gershoff, E. T., \& Bringewatt, E. H. (2016). Violence exposure as a mediator between parenting and adolescent mental health. Child Psychiatry \& Human Development, 48, 235-247.

Moradian, J., Alipour, S., \& Shahani-Yailagh, M. (2014). The causal relationship between parenting styles and academic performance mediated by the role of academic self-efficacy and achievement motivation in the students. Journal of Family Psychology, 1, 63-74.

Niaraki, Fahimeh Rezai., \& Hassan Rahimi. (2012). The impact of authoritative, permissive and authoritarian behavior of parents on self-concept, psychological health and life quality. European Online Journal of Natural and Social Sciences, 2(1), 78-85.

Pellerone, M., Tolini, G., \& Polopoli, C. (2016). Parenting, identity development, internalizing symptoms, and alcohol use: A cross-sectional study in a group of Italian adolescents. Neuropsychiatric Disease and Treatment, 12, 17691778.

Pham, Huong TM., \& Betsy, Ng. (2019). Selfesteem as the mediating factor between parenting style and creativity.
International Journal of Cognition and Behavior, 2(1).

Pong, Suet-ling., Johnston, Jamie., \& Chen, Vivien. (2009). Authoritarian parenting and asian adolescent school performance: Insight from the US and Taiwan. International Journal of Behavioral Development, 34(1), 62-72.

Purnomo, Aldy Rochmat. (2016). Analisis statistik ekonomi dan bisnis dengan SPSS [Analysis of economic and business statistics with SPSS]. Ponorogo: WAGE Group.

Rachmawati, Yeni., \& Kurniati, Euis. (2012). Strategi pengembangan kreativitas pada anak usia taman kanak kanak [Creativity development strategies in kindergarten children]. Jakarta: Kencana Prenada Media Group.

Sharp, Caroline. (2001). Developing young children's creativity through the arts. National Foundation for Educational Research. London.

Siregar, Syofian. (2014). Statistik parametrik untuk penelitian kuantitatif dilengkapi dengan perhitungan manual dan aplikasi SPSS versi 17 [Parametric statistics for quantitative research equipped with manual calculation and application of SPSS version 17]. Jakarta: PT Bumi Aksara.

Stewart \& Koch. (1983). Children development through adolescence. Canada: John Wiley and Sons, Inc.

Sujarweni, V. Wiratna. (2014). Metode penelitian: Lengkap, praktis, dan mudah dipahami [Research methods: Complete, practical, and easy to understand]. Yogyakarta: Pustaka Baru Press.

Tanhaye-Reshvanlou, F., \& Hejazi, E. (2009). Understanding the relationship between parenting style and academic motivation 
278 | Jurnal Pendidikan Progresif, Vol. 10, No. 2, pp. 267-278, August 2020

and academic achievement of high school students. Journal of Scholar Behavior, 39, 1-14.

Tavassolie, T., Dudding, S., Madigan, A. L., Thorvardarson, E., \& Winsler, A. (2016). Differences in perceived parenting style between mothers and fathers: Implications for child outcomes and marital conflict. Journal of Child and Family Studies, 25, 2055-2068.

Theresya, J., Melly, L., \& Neti, H. (2018). The effect of parenting style, self-efficacy, and self regulated learning on adolescents' academic achievement. Journal of Child Development Studies, 03(1), 28-43.

Wood, E. E., \& Kennison, S. M. (2017). Young children's risk-taking: Mothers' authoritarian parenting predicts risktaking by daughters but not sons. Child Development Research, 1-8.

Yaffe, Y. (2017). Establishing specific links between parenting styles and the sanxieties in children: Separation, social, and school. Journal of Family Issues, 39(5), 1419-1437. 
